\title{
Use of Panel Data for Assessing Socio-Economic Situation in the Northern Regions of Krasnoyarsk Krai
}

\author{
Anna R. Semenova* and Irina M. Popelnitskaya \\ Siberian Federal University \\ 79 Svobodny, Krasnoyarsk, 660041, Russia
}

Received 12.10.2017, received in revised form 22.10.2017, accepted 16.11.2017

\begin{abstract}
The development of resource regions in Siberia including the Northern Areas of Krasnoyarsk Krai falls within the scope of priority economic and geopolitical interests of this country. The strategic development of the resource regions in Northern Arctic Territories squares off against a set of particularly urgent environmental, economic and social problems such as a declining quality of life, labor shortages, increasing transformation rate of the resource-based potential. In this regard, to make the resource regions' development management even more efficient it is necessary to implement up-top scientific methods and mechanisms on decision-making, forecasting and monitoring of the regional economy. The research novelty is related to formulation of econometric techniques and spatial economics model system relying on panel (longitudinal) studies for assessing spatial development of the regional economy in general and its elements in particular. Firstly, this approach measures how not merely system changes, but also certain management decisions impact the rate of regional development, and secondly-allows for statistically valid matching among different Northern Areas in Russia and other countries. An integrated initial sampling includes urban areas and 56 municipal districts of Krasnoyarsk Krai in 2007 - 2015.

This research has defined economic, social and environmental indicators for the Arctic Zone in Krasnoyarsk Krai and in the Evenk District included into an absolutely discomfort and extremely discomfort zones on bioclimatic indicators. The climatic approach based on the July isotherm allows classifying this territory as the Arctic one. The average monthly temperatures in July vary from $+13{ }^{\circ} \mathrm{C}$ to $+15^{\circ} \mathrm{C}$, in January from -34 to $-38^{\circ} \mathrm{C}$ that is adequate to the Arctic Zones. The frost lasts there for $240-275$ days. The panel studies highlight the following general tendencies: a strongly-pronounced asymmetry in the development of the Arctic Zone and similar territories of Krasnoyarsk Krai; trends in the basic economic, social and ecologic indicators; economic decline in the resource-based regions on the back of normalized data for all the areas of Krasnoyarsk Krai; this decline does not improve ecologic state of these territories; lack of positive dynamics in the social indicators under increased investments into the fixed capital per capita.
\end{abstract}

Keywords: Arctic Zone, territorial management, socio-economic and environmental state of the territory, socio-economic inequality, living standards, forecasting and monitoring of the regional economy, panel (longitude) studies.

This research has been conducted under the Grant of the Russian Foundation of the Humanities № 16-12-24023 "Methodology of Modeling and Forecasting of Development Scenarios for the "Green Economy" and Regional Bio-economy in the Context of Economic Exploration of the Arctic Zone's Resources".

DOI: 10.17516/1997-1370-0192.

Research area: economics.

(C) Siberian Federal University. All rights reserved

* Corresponding author E-mail address: annrs@mail.ru 


\section{Introduction}

A heightened interest of the world community to the Arctic Zone (AZ) is explained by its hyper availability of resources. The Arctic Zone of the Russian Federation is not an exception since it contains a half of forest and woodworking industry, manufacturing of rough diamonds, cobalt, platinoids and apatite concentrate $-100 \%$; extraction of natural gas, copper and nickel $90 \%$, also of more than $75 \%$ - oil and more than $65 \%$ - gold (Zaykov et. al: 30 ).

The richest availability of natural resources determines a dominant role of mining and processing industries in the northern economy, that, at some point, hugely impacts weak and slowly recovering eco-systems in the Northern Areas.

As for the modern Russia, the problem of socio-economic development in the Far North Regions and exploration of the natural assets there are one of the most urgent issues. The Arctic Zone of the Russian Federation has been shaped under the Decree of the President of the Russian Federation No. 296 on May 2, 2014 "On the Land Territory of the Arctic Zone of the Russian Federation".

In total, Russia controls almost $3 \mathrm{mln} \mathrm{km}^{2}$ of the Arctic Territories - that is $18 \%$ of the whole country (Fig. 1). By climatic conditions this region can be considered among discomfort and extremely discomfort zones that imposes restrictions on many household activities and makes them almost unsuitable for living. As little as $2.2 \mathrm{mln} \mathrm{km}^{2}$ of these lands are inhabited by people (slightly over than $2.5 \mathrm{mln}$ people). This is less than $2 \%$ of Russia's population (146.8 mln people) and less than $50 \%$ of the whole Arctic's population (4.6 mln people) including its segments in Europe and America (Fauzer et al., 2016: 44).

The AZ covers more than $30 \%$ of the total Russia's territory. In this context, $28 \%$ of the AZ accounts for the Northwestern Federal Okrug comprising Murmansk Oblast, the Republic of Karelia, Arkhangelsk Oblast, the Republic of Komi and Nenets Autonomous Okrug. Ural Federal Region which also includes Yamalo-Nenets Autonomous Okrug takes 14\%; the Far Eastern Federal Okrug with the Republic of Yakutia and Chukotskiy Autonomous Okrug $38 \%$ and $20 \%$ is taken by Siberian Federal Okrug with Krasnoyarsk Krai inside (Fig. 2).

Almost a third of the Russian Federation's territory is inhabited by merely $8 \%$ of the whole population. This fact can be explained by severe climate in the Far North region. The population density and size distributed across the federal entities are uneven (Fig. 3). The population density $\min$ is in the AZ of Chukotskiy Autonomous Okrug -0.07 people $/ \mathrm{km}^{2}$, in the AZ of Krasnoyarsk Krai -0.12 people $/ \mathrm{km}^{2}$, while the

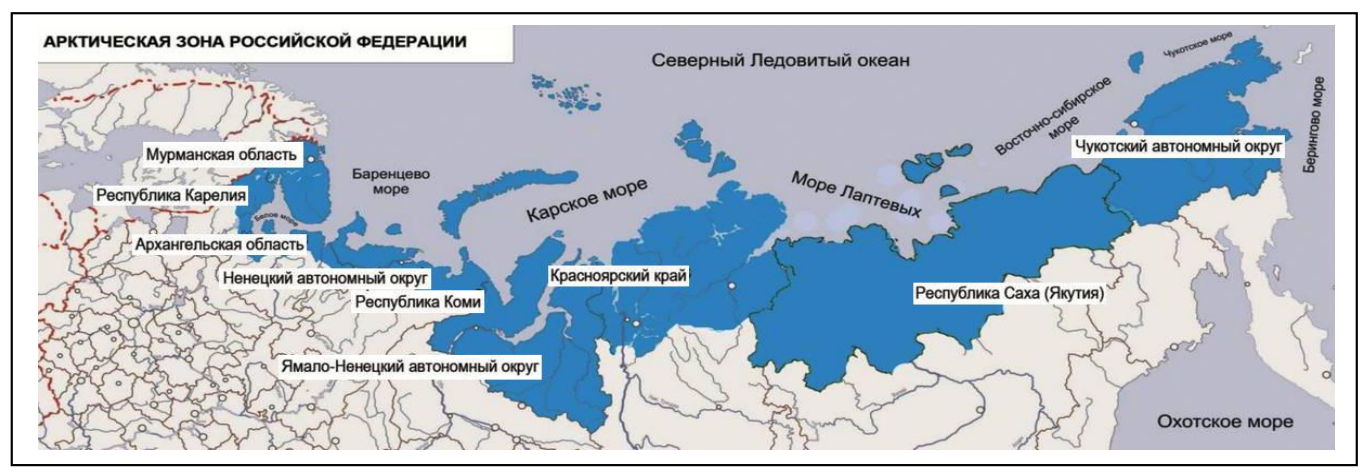

Fig. 1. Borders of the Arctic Zone of the Russian Federation 


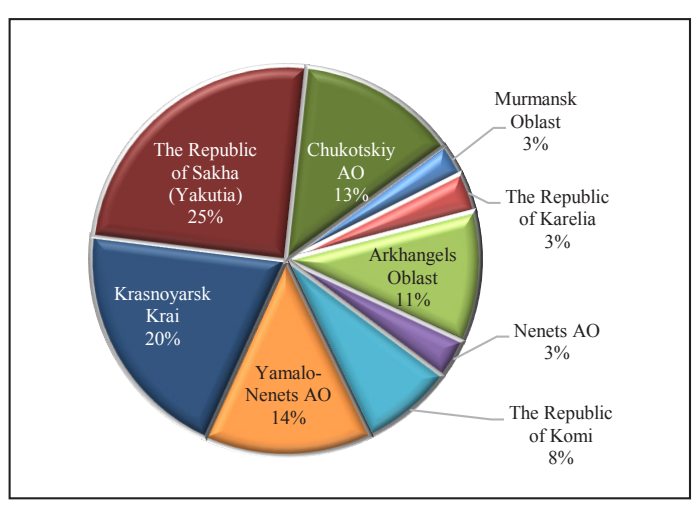

Fig. 2. Areas of the Russian Federation's Subjects Included into the Arctic Zone

max is in Murmansk Oblast -5.23 people $/ \mathrm{km}^{2}$ with the average density of 8.4 people $/ \mathrm{km}^{2}$ over the country, given that the proportion of urban population is $80 \%$.

\section{The Arctic Zone of Krasnoyarsk Krai}

The Arctic Zone of Krasnoyarsk Krai includes the Turukhansk and the Taimyr (Dolgano-Nenets) Districts and Norilsk. In this research we have also analyzed the Evenk District (Fig. 4) since regarding its climatic conditions it can represent the territory of absolutely discomfort or extremely discomfort zones. The climatic approach based on the July isotherm allows classifying this territory as the Arctic one. The average monthly temperatures in July vary from $+13^{\circ} \mathrm{C}$ to $+15^{\circ} \mathrm{C}$, in January - from -34 to $-38^{\circ} \mathrm{C}$ that is adequate to the Arctic Zones. The freezing weather lasts there for 240 - 275 days as well.

The Arctic Zone in this region expands over 1837 ths $\mathrm{km}^{2}-79 \%$ of the whole territory of Krasnoyarsk Krai and a little less than $11 \%$ of the whole Russia.

\section{Research objects and methodology}

This work is based on the longitude (panel) studies is a special type of investigation (social, economic or ecologic) which suggests numerously repeated measures of one or more considered

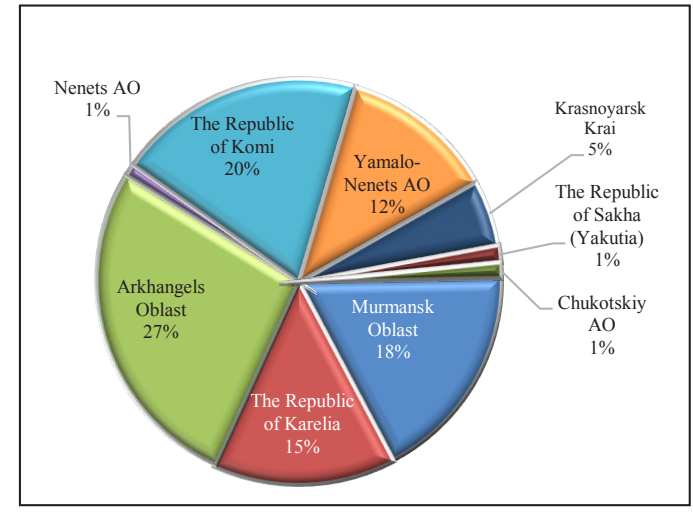

Fig. 3. Population distribution in the Arctic Zone among the Federal Subjects

variables of a social object through the example of same or similar study groups.

As a rule, such researches diachronically address development trends or changes in certain process or phenomenon.

\section{Problem statement and basic terms}

To analyze and forecast any further development of the Russian resource-based regional economies in the terms of spatial

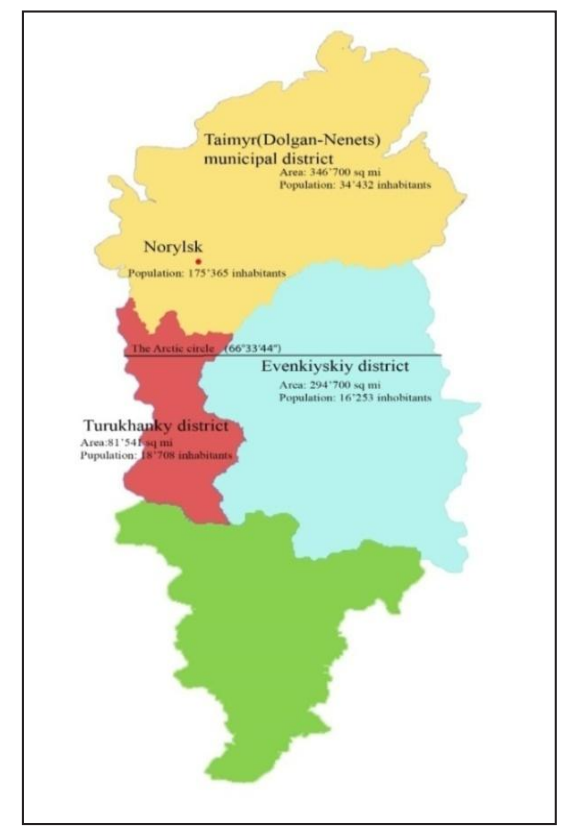

Fig. 4. Northern Areas of Krasnoyarsk Krai 
inequality and asymmetry, it is necessary to identify the panel studies parameters which would involve selection and monitoring units and period.

\section{Objects}

Originally, the observation panel consists of 56 municipal districts of Krasnoyarsk Krai. In a consequence, among these entities we have chosen the northern and similar areas.

\section{Period}

This research monitors and analyzes the period of 2007 - 2015 with possible information extension on municipal entities. Such beginning for the monitoring period reflects possible comparability of the panel data related to the changes in the administrative and territorial division of Krasnoyarsk Krai and complex statistics posted in the site of Federal State Statistic Service in Krasnoyarsk Krai, ANCO "Information Publishing Center "Statistics of the Krasnoyarsk Territory" and in the Ministries and Departments of the Krasnoyarsk Krai.

\section{Variables}

The analysis has been grounded in three indicator vectors, i.e. economic, social and environmental states of the krai's territories; each of these vectors contains not less than 15 indicators. The list and evidences for these indicators have been introduced in (Semenova, 2015: 155-163).

The statistic analysis of obtained ecologic and economic indexes (reference) has provided us with three temporary defining points which most accurately describe their transformations: 2007, 2011 and 2014. These years, in turn, have been further used to compare the territories.

\section{Results and Discussion}

While considering the economic development of Krasnoyarsk Krai's regions, one should also bear in mind their resource-based uniqueness and marketability shifts. These indicators assess investments and production capacity of the territory. As a temporal regional development dynamics we have regarded only certain economic indicators (since the analysis of all the indicators involved is quite consuming).

In our observation, one of the most important economic indicators is the volume of shipped goods produced domestically (ths rub). Its spatial-time dynamics is demonstrated in Fig. 5.
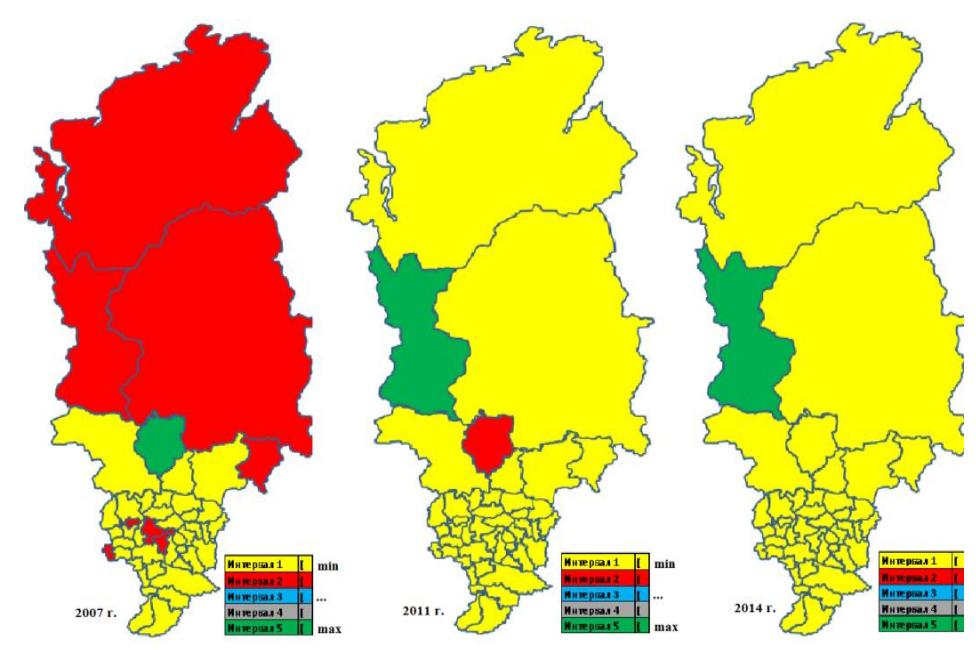

Fig. 5. Volume of shipped goods produced domestically (ths rub) 
Many of the municipal districts in Krasnoyarsk Krai including the Taimyr (Dolgano-Nenets) and the Evenk Districts have experienced a decline in this indicator in 2007 2014. In this case, Turukhansk District might be an exception - it has indicated an increase in 2011 up to 241010082,6 ths rub and reached the maximum in $2014-282991876,1$ ths rub as well as Norilsk that also has tended to improve this measure throughout the whole period from 355845188,5 ths rub in 2007 to 420905156,2 ths rub in 2014 (Semenova, 2017: 417-422).

The region's investment appeal is one of the most crucial indicators in the set of economic, political, social and natural conditions where this territory exists and develops.

Fig. 6 demonstrates changes in the dynamics of investment flows into the fixed capital per capita. The positive dynamics of investment activity in the Northern Areas is determined by regional and federal implementation of measures aimed at improving the business environment. In the considered period, 2007 -2014, a leading position on this indicator has been given to the Turukhansk District. The situation has also been changed for the better by 2014 when some regions - the Taimyr
(Dolgano-Nenets) and the Evenk Districts have also experienced a significant investment increase (Fig. 6).

Regarding the aspect of population appeal, no less important measure is the level of monthly average wage paid (Fig. 7). Yet, the dynamics of monthly average nominal wage paid is slightly different and invariant. Merely only the Turukhansk District has been constant on this indicator: the amount of wage there is the highest in the Krai and consistent with other indicators under the analysis (Fig. 5-7). In the Taimyr (Dolgano-Nenets) District this measure has increased in 2011 in comparison with 2007 (Fig. 7) and decreased in 2014 on the back of remarkable growth of the investment capital (Fig. 6). The Evenk District keeps the level with the dynamics of shipped goods produced domestically and the investment amount improved in 2014 has not influenced this indicator (Fig. 5, 7).

In the modern context - particularly for the Northern Areas - the most socio-economically index is changes in recorded unemployment. It has faced its max in 2007 in the Turukhansk District. The Taimyr (Dolgano-Nenets) District has managed to put this indicator down in 2011 and maintained this level in $2011-2014$.
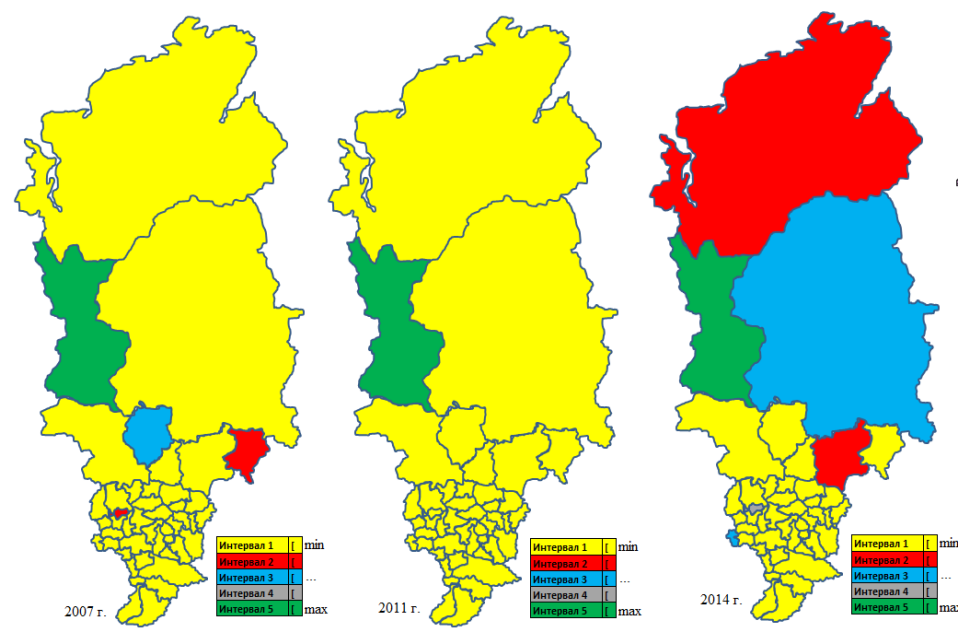

Fig. 6. Dynamics in the investments in the fixed capital, per capita 
Thus, all the territories are characterized by the dynamic development on the indicators and by the absence of positive trends within the increased investment. Positive trends can only be found in the Turukhansk District.

To measure the social, ecologic and economic state of the districts and compare all the indicators, we have carried out a rating analysis for all the areas: it has led us to another comparative study. At this stage we have drawn a coordinate system in which the axes reflect the integral indexes. The first quadrant relates to positive integral indicators on the $\mathrm{X}$-axis and the Y-axis; the second - to positive indicators on the $\mathrm{Y}$-axis and negative on the $\mathrm{X}$-axis; the third one shows us only negative measures and the forth positive measures on the $\mathrm{X}$-axis and negative on the Y-axis.

The analysis of socio-economic condition of the Northern Areas on these integral indicators in 2007 is demonstrated in Fig. 9. On these indicators' rate the Northern Areas are located in the first quadrant. The highest integral socio-economic measures among the Northern

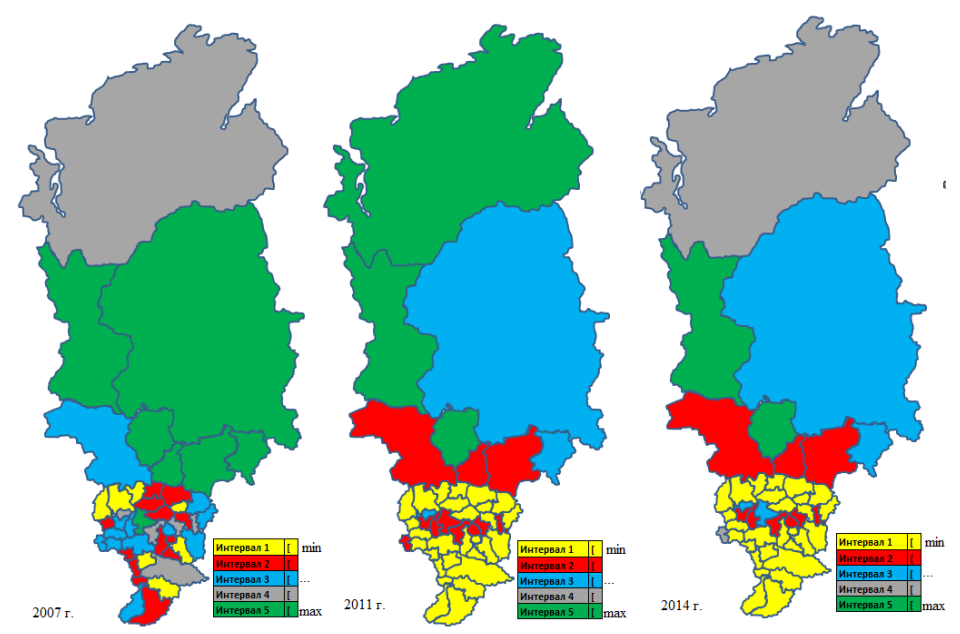

Fig. 7. Dynamics of the monthly average nominal wage paid for employees
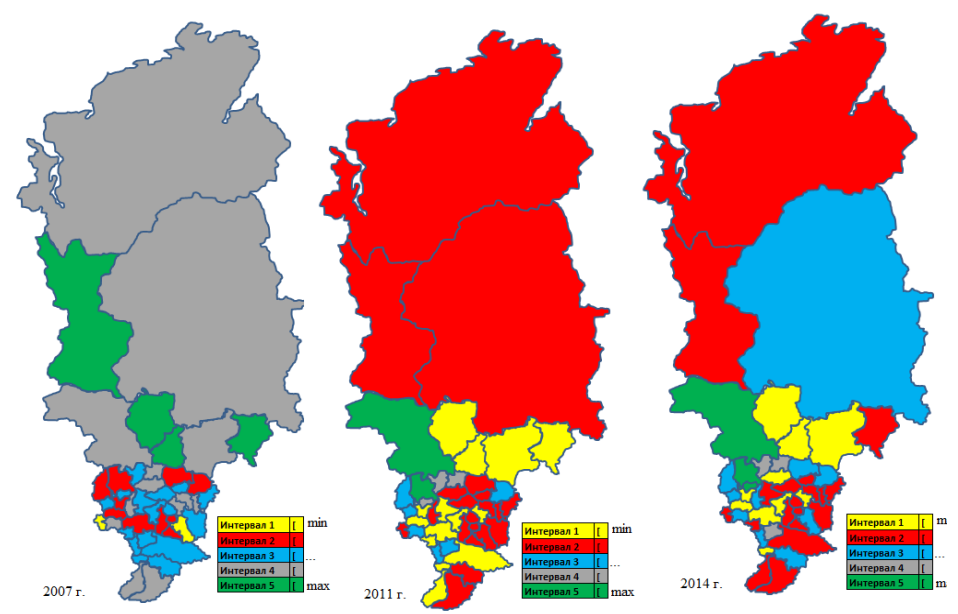

Fig. 8. Recorded unemployment rate 
and other areas have been registered in Norilsk. The Taimyr (Dolgano-Nenets) District has high economic, but also low social indicators in comparison with other northern areas of the Krai. The strongest social performance and the weakest economic results have been shown in the Evenk District. In general, the analysis of integral economic and social indicators has allowed matching all the Northern Areas to the first quadrant that is likely to reflect the social and economic sustainability in comparison with other municipal districts in Krasnoyarsk Krai.

The analysis of socio-economic situation of the Northern Areas on these integral indicators in 2014 is demonstrated in Fig. 9. Among all the Northern Areas only the Turukhansk District has shown certain improvements in the integral socio-economic indicators. The economic measures of the Taimyr (Dolgano-Nenets) District and the Evenk District, as well as of Norilsk, have considerably declined given that the social sphere remains at the level of 2007. Consequently, the increase in investments in the Evenk and the Taimyr (Dolgano-Nenets) Districts has not caused any enhancement in the social and economic spheres.

The environmental assessment of the territory can be conducted in order to identify the most urgent ecological issues and to determine the extent of any given problem or taken in their entirety (Lukin, 2013: 17). Certain environmental indicators can be addressed through the angle of population appeal and health rate in this territory (Semenova et al., 2017: 420), but, at the same time, it should be remembered that any chronic effects may cause irreversible processes in the eco-system. As so, any anthropogenic factors may have severely detrimental influence on weak and slowly recovering eco-systems in the Northern Areas.

It is known that the effect of the environment is directly depends on the economic development-

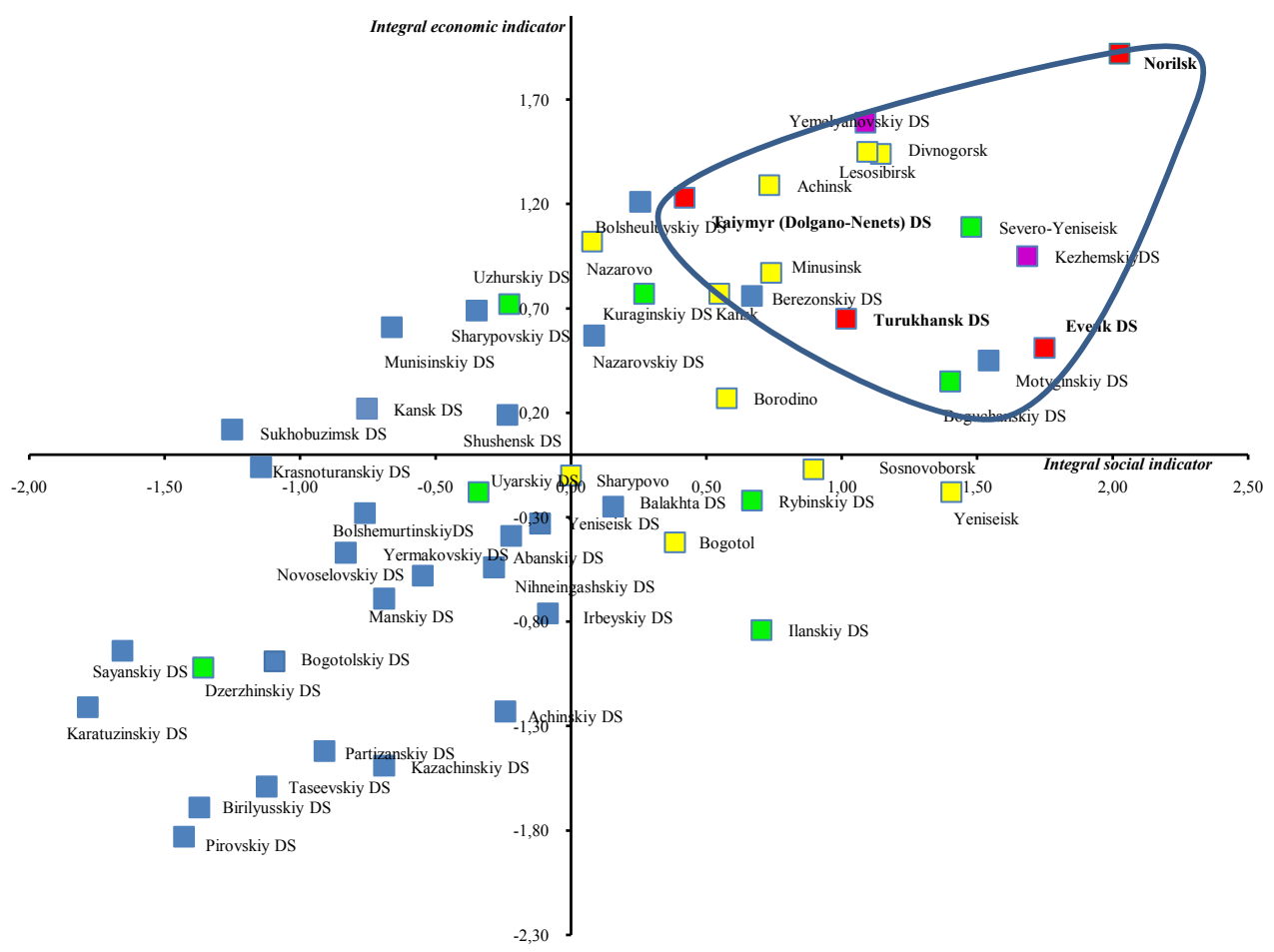

Fig. 9. Socio-economic situation in 2007 
especially in the resource-based regions. Thus, it is interesting to measure the states of areas on their environmental and economic indicators. In 2007 all the Northern Areas remain in the third quadrant (Fig. 11) underlining positive economic indicators and strong anthropogenic influence on the environment. As the analysis has shown, Norilsk has been given the last place on the integral environmental indicators.

In 2014, despite a sharp deterioration in the economic indicators in Norilsk and the Taimyr (Dolgano-Nenets) District, the environmental situation has not improved. Only the Evenk District has shown a slight drop in the effects on the environment provided quite a strong decrease in the economy. In the Turukhansk District, the increase in economy has determined the environmental degradation (Fig. 12). The most stable development on all the indicators can be seen in the Turukhansk District: under remained strong investments its social indicators stay the same, and its economic indexes increase. On the back of these processes, there has been a little decrease in the environmental indicators.

\section{Conclusion}

The conducted research has identified economic, social and environmental indicators for the Arctic Zone in Krasnoyarsk Krai and in the Evenk District included into absolutely discomfort and extremely discomfort zones on bioclimatic indicators. The climatic approach based on the July isotherm allows classifying this territory as the Arctic one. The average monthly temperatures in July vary from $+13{ }^{\circ} \mathrm{C}$ to $+15{ }^{\circ} \mathrm{C}$, in January - from -34 to $-38{ }^{\circ} \mathrm{C}$ that is adequate to the Arctic Zones. The frost lasts here for $240-275$ days. The panel studies highlight the following general tendencies: a stronglypronounced asymmetry in the development of the Arctic Zone and similar territories of Krasnoyarsk Krai; trends in the basic economic,

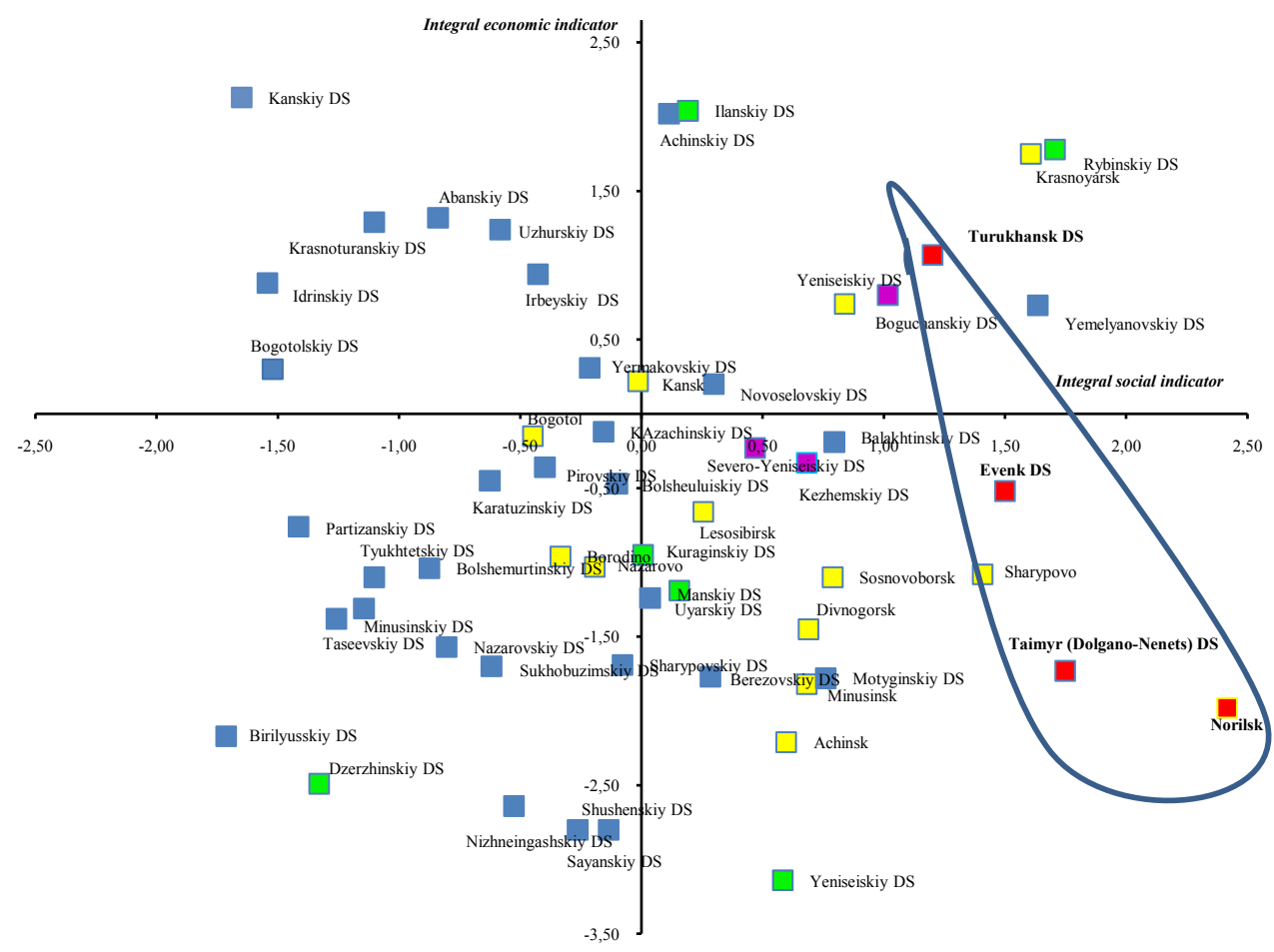

Fig. 10. Socio-economic situation in 2014 


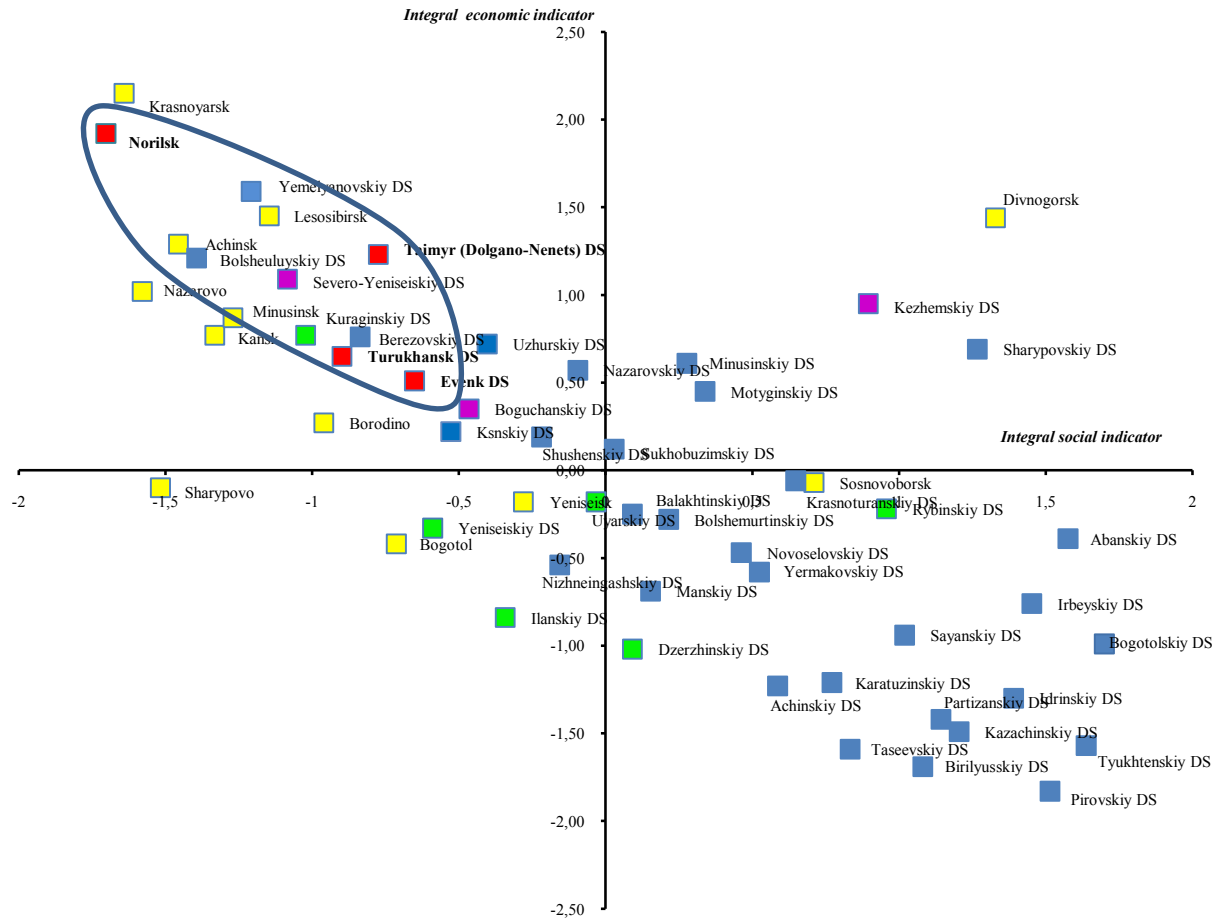

Fig. 11. Economic and social situation in 2007

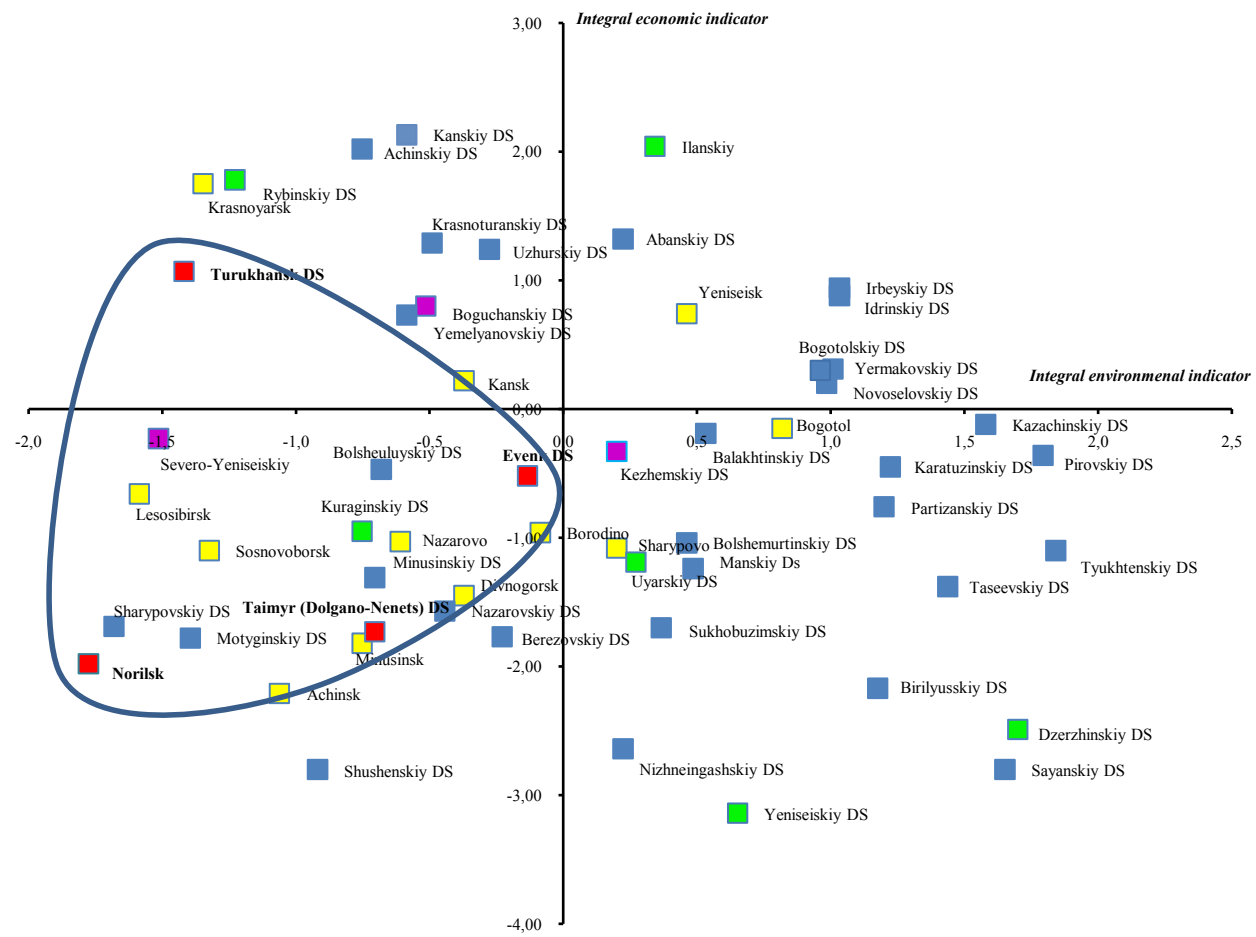

Fig. 12. Economic and environmental situation in 2014 
social and environmental indicators; economic decline in the resource-based regions on the back of normalized data for all the areas of Krasnoyarsk Krai; this decline does not improve the environmental condition of these territories; lack of positive dynamics in the social indicators under increased investments into the fixed capital per capita.

\title{
References
}

Fauzer, V.V., Lytkina, T.S., Fauzer, G.N. (2016). Osobennosti rasseleniia naseleniia v Arkticheskoi zone Rossii [The Features of Population Distribution in the Russian Arctic Zone], In Arktika: ekologia i ekonomika [The Arctic: Ecology and Economy], 2(22), 40-50.

Lukin, Yu.V. (2013). "Goriachie tochki” Rossiiskoi Arktiki ["Hot Zones" of the Russian Arctic], In Arktika i Sever [The Arctic and the North], 11, 4-39.

Semenova, A.R. (2015). Asimmetriia sotsial'no-ekonomicheskogo i ekologicheskogo polozheniia territorii arkticheskoi zony Krasnoyarskogo kraia [Asymmetry in Socio-Economic and Environmental Sate of the Arctic Zone of Krasnoyarsk Krai], In Sbornik nauchnyh trudov "Prirodnye resursy $i$ kompleksnoe osvoenie pribrezhnykh raionov Arkticheskoi zony" [Scientific Collection "Natural Resources and Integrated Exploration of the Arctic Zone's Coastal Areas], 155-163.

Semenova, A.R., Popelnickaya, I.M., Bukharova, E.B., Razumovskaya, V.A., Bukharov, A.V. (2017). Analysis of morbidity rate of the population at the Artic territories on the extent of commercial development and ecological state on the example of Krasnoyarsk Krai, In 4th International Multidisciplinary Scientific Conference on Social Sciences and Arts SGEM 2017, 3(11), 417-422.

\section{Использование панельных данных}

\section{Для оценки социально-экономического положения} северных регионов Красноярского края

\author{
А.Р. Семенова, И.М. Попельницкая \\ Сибирский федеральныгй университет \\ Россия, 660041, Красноярск, пр. Свободный, 79
}

Развитие ресурсных сибирских регионов, включая северные территории Красноярского края, входит в сферу приоритетных экономических и геополитических интересов страны. Стратегическое развитие ресурсных регионов сталкивается с комплексом экологических, экономических и социальных проблем, особо остро стоящих перед северными арктическими территориями, таких как снижение качества жизни населения, дефицит трудовых ресурсов, увеличение скорости трансформации природно-ресурсного потенциала. В связи с этим для увеличения эффективности управления развитием ресурсных регионов необходимо внедрение новых современных научных методов и инструментов принятия решения, прогнозирования и мониторинга экономики региона. Новизна данного исследования связана с разработкой эконометрических методов и системы моделей пространственной экономики, опирающихся на панельные (лонгитюдные) исследования, позволяющие оценить пространственное развитие как экономики региона в иелом, так и отдельных ее составляющих. Данный подход позволяет оценить силу влияния на уровень развития региона не только системных изменений, но и отдельных частных управленческий решений, а также проводить статистически достоверные 
сопоставления с различными северными территориями России и других стран. Единая стартовая выборка включала городские округа и 56 муниципальных районов Красноярского края в период с 2007 по 2015 г.

При проведении исследования были определены экономические, сочиильные и экологические показатели состояния арктических территорий Красноярского края и Эвенкийского района, который по биоклиматическим показателям входит в абсолютно дискомфортную и экстремально дискомфортную зоны. Климатический подход, основанный на июльской изотерме, позволяет отнести данную территорию к арктической. Средние месячные температуры июля от $+13^{\circ} \mathrm{C}$ до $+15^{\circ} \mathrm{C}$, января-минус 34-38 ${ }^{\circ} \mathrm{C}$, что сопоставимо с территориями Арктической зоныл. Морозы длятся 240-275 дней. Панельные данные позволили выявить общие тенденции: ярко выраженную асимметрию в развитии арктических и приравненных к ним территорий Красноярского края; динамику изменения основных экономических, социальных и экологических показателей; ухудшение экономических показателей ресурсных регионов на фоне нормализованных данных по всем территориям Красноярского края; снижение экономических показателей не улучшает экологических показателей территорий; отсутствие положительной динамики в социальных показателях при увеличении инвестиций в основной капитал на душу населения.

Ключевые слова: Арктическая зона, территориальное управление, социально-экономическое и экологическое состояние территории, сочиально-экономическое неравенство, качество жизни населения, прогнозирование и мониторинг экономики региона, панельнье (лонгитюдные) исследования.

Работа выполнена при поддержке гранта РГНФ № 16-12-24023 «Методология моделирования и прогнозирования сиенариев развития «зеленой экономики» и биоэкономики регионов в условиях активного хозяйственного освоения ресурсов Арктической зоны».

Научная специильность: 08.00.00 - экономические науки. 